\title{
THE LEGAL STRENGTHENING IN OUR EXISTENCE INDONESIAN LAW CONSTRUCTION
}

\author{
Rakhmat Bowo Suharto \\ Sultan Agung Islamic University \\ rakhmat@unissula.ac.id
}

\begin{abstract}
The concept of nationality which has been formalized juridically in the Constitution of the State and the State Constitution, is not free from examination. Starting from rebellions based on ethnicity, religion, and political ideology, the nation has experienced. The approach method uses a normative juridical approach. The approach taken to find solutions to problems of legal problems that arise is to use a statutory approach. The results of the research achieved include strengthening the law as a means as a legal system that overcomes the entire existing local legal system, the Indonesian legal system has put in place various integrating tools which are at the same time a national identity that supports pluralism in the building of the Republic of Indonesia. Law has played an important role so that the existence of the Republic of Indonesia is protected from division. The purpose of maintaining unity in order to maintain the existence of the Republic of Indonesia, the law needs to be strengthened by conducting a paradigmatic evaluation of existing legal constructs.
\end{abstract}

Keywords: Strengthening Law; Existence; Standard Clause; Legal Construction.

\section{A. INTRODUCTION}

Constitution of the Republic of Indonesia in 1945 Article 1 (1) states that the State of Indonesia is a unitary state of the Republic. Then in paragraph (2) and sovereignty is in the hands of the people and carried out in accordance with the Constitution of Paragraph (3) Indonesia is a State of Law. ${ }^{1}$

Theoretically, nationalism is motivated by the belief that a political community that can be expected for its ability to guarantee human welfare, safety and survival in the world (which is full of competition) is only a political community that can stand up and successfully integrate local units. who have the same identity. ${ }^{2}$ The big problem faced by the pioneers of independence and the founders of the state at that time was how to build a national life on the foundation of socio-cultural diversity rooted in a

1 Uyunun Nafisa, Siti Rodhiyah Dwi Istinah, Implementation Of The Vocation School of Legislation Agency In Village Consultative Department Agreement (Study of The Implementation The Sriwulan Village BPD Sayung, Demak), Jurnal Pembaharuan Hukum, Volume VI No.1 January-April 2019, page.11-25

2 Soetandyo Wignjosoebroto, 2002, Hukum Paradigma, Metode dan Dinamika Masalahnya, Lembaga Studi dan Advokasi Masyarakat (ELSAM) dan Perkumpulan untuk Pembaharuan Hukum Berbasis Masyarakat dan Ekologi (HuMa), Jakarta, page. 545-546. 
substructure called ethnicity, ethnicity, or other collective units, both cultural and religious.

The history of the Indonesian state administration notes that efforts to build unity on top of diversity actually happened long before the days of independence. In the days of the Majapahit Empire, for example, life together in a situation of diversity was accepted as commonplace, and this is reflected in the expression of Mpu Tantular in his book Sutasoma, namely: "Bhinneka Tunggal Ika tan Hana Dharma Mangrwa", different but one, no religion. who are ambiguous. During the period of the movement, the use of a new Indonesian identity began to show its seeds since the establishment of Indische Vereeniging which in 1922 changed its name to Indonesische Vereeniging, and finally in 1924 it was changed to the Association of Indonesia. The political ideology of the Indonesian Association is Indonesian independence which requires four principles, namely national unity, solidarity, non-cooperation and independence.

After that, an important milestone was the holding of the Second Indonesian Youth Congress which was held on 26-28 October 1928 which pledged the Youth Pledge to have one homeland, one nation, and one language, namely Indonesia. In the preparations for independence, national commitments were seen from the discussions that emerged at BPUPKI sessions $^{3}$. The spirit of unity is at least reflected in the composition of the BPUPKI membership which more or less represents the various elements of the Indonesian nationality at that time. ${ }^{4}$ The important thing that reflects how the founders of this country have a high national spirit, namely that almost all BPUPKI members when meeting to formulate the basis of the state and the constitution, emphasize the importance of unity as the foundation for the establishment of an independent Indonesia. ${ }^{5}$

In Sukarno's view, the national building of Indonesia was a broad nationality which he called a "nationale staat". The national building was not only united because of the same history as a nation that was colonized, but also because of the desire to unite. ${ }^{6}$ To form Indonesia's "nationale staat", the will to unite and a common history is not enough. It is necessary to have unity regarding the view of life as the basis of nationality, geopolitical unity which indicates the territory of the nation state, unity of the nation's citizens from each population, a unity of government which administers the national government, unity of culture, language, state symbol, and national anthem as national identity.

The concept of nationality which has been formalized juridically in the Constitution of the State and the State Constitution, is not free from examination. Starting from rebellions based on ethnicity, religion, and political ideology, this nation has experienced. Even through juridical

3 Soepomo, Pergulatan Tafsir Negara Integralistik, Thafa Media, Yogyakarta, 2015, page.207208

4 Ibid., page. 208.

5 Yudi Latif, 2015, Negara Paripurna, Historisitas, Rasionalitas, dan Aktualitas Pancasila, Gramedia Pustaka Utama, Jakarta, page. 328-331.

6 Soetandyo Wignjosoebroto, Op., Cit, page. 516. 
channels that changed the form of the state and the government system with the enactment of the RIS Constitution, this has also happened. In fact, NKRI has remained standing up to this moment. This cannot be separated from the strong commitment of this nation in upholding unity in order to defend the national home of Indonesia.

The purpose of this research is to find out and analyze the strengthening of law in order to maintain the existence of Indonesian legal constructions, thus, state politics for Indonesia is important to maintain the integrity and sustainability of the nation, and that means placing the law as an important instrument to maintain the existence of the Republic of Indonesia.

\section{B. RESEARCH METHODS}

This research employed normative juridical research method, ${ }^{7}$ in which the data were obtained from literature study by using secondary data. The secondary data are not obtained directly from the field but from library materials. The data collected were then descriptively analyzed. This research is expected to obtain a clear, detailed, and systematic picture of the problem being studied, while it is analytical, meaning that it does not merely explain, but also describes and analyzes the content and structure of the positive law that applies. ${ }^{8}$

\section{RESULT AND DISCUSSION}

\section{The Role of Law as an Integrating Instrument in a Nation State}

The legal system actually describes the form of law in a country, therefore when a legal system is born from structure, substance and culture, the legal system in a country must reflect the country's identity. The birth of the legal system is influenced by many factors, such as economic, political and social. This means that the legal system may be born due to external factors, not internal values of the state itself. So to ward off thin similarities and differences in a legal system, it would be better to look for a legal system that is appropriate and in line with the identity of a country. ${ }^{9}$

The Indonesian National Law System which is still trying to find a form or format that is in accordance with the spirit and spirit of the Proclamation and the values contained in society and added by not denying the enormous influence of other legal systems both culturally and legally has its own consequences in the formation of society in the development of national law. It takes a single legal system, namely a national legal system that becomes a reference for the implementation of social, political and cultural life for all residents of the nation state. As a

7 Zulfadli Barus, Analisis Filosofis Tentang Peta Konseptual Penelitian Hukum Normatif Dan Penelitian Hukum Sosiologis, Jurnal Dinamika Hukum, Vol. 13 No.3. September 2013, page. 307-318.

8 Bahder Johan Nasution, Metode Penelitian I/mu Hukum, Cetakan Kedua, Mandar Maju, Bandung, 2016, page. 91.

9 Emy Hajar Abra, Perubahan Sistem Hukum Menuju Jati Diri Sebuah Negara, Jurnal Pembaharuan Hukum, Volume III No. 2 May - August 2016, page. 264-273 
newly independent nation state, a national legal system was established after the declaration of Indonesian Independence on 17 August $1945 .^{10}$

Through the statement of independence, it means that the Indonesian nation has broken ties with the previous legal system, namely the Dutch East Indies legal system and the Japanese occupation legal system. Thus, the Proclamation of Independence is the first norm that makes the Indonesian nation state as an organization of power to have sovereignty and authority to regulate and determine laws that want to be a reference for state administration. ${ }^{11}$

The idea of the welfare state has shifted the tasks of the government which was limited to maintaining the security of its citizens, becoming more responsible for the welfare of the community. his active nature of power makes it impossible for the Government to merely have the power to implement the law. He must be given broad authority in order to realize the welfare of citizens. ${ }^{12}$

Indonesia is a country based on law. Everything concerning the general welfare has been regulated in law in the form of written regulations. Thus, legal certainty for a person is essentially guaranteed by the constitution in Indonesia. As a law that addresses the entire existing local legal system, the Indonesian legal system has put in place various integrating tools which are at the same time a national identity that supports pluralism in the building of the Republic of Indonesia. ${ }^{13}$

a. Whereas the concept of nationality, which is based on a shared history as a colonized nation, can clearly be seen in the formulation of the Jakarta Charter which was later stated in the Preamble of the 1945 Constitution, namely a view of life together that can unite all elements of individuals and groups as the basis of nationality. ${ }^{14}$

b. Whereas the law has also stipulated a unified life view called Pancasila which is contained in the Fourth Paragraph of the Preamble of the 1945 Constitution.

c. Affirmation of the unity of the Indonesian territory in the form of a unity of islands from Sabang to Merauke which form a single territorial unit. Regarding this matter, no formulation can be found in the 1945 Constitution. Regarding territorial unity, through the Juanda Declaration on December 13, 1957, the Government of Indonesia was able to confirm the claim regarding the concept of an archipelago which was later recognized by the United Nations through the 2nd United Nation Convention on the Law of the Sea

10 Oksep Adhayanto, Perkembangan Sistem Hukum Nasional, Jurnal Ilmu Hukum, Volume 4 NO. 2 February-July 2014, page.207-228

11 Joeniarto, Sejarah Ketatanegaraan Republik Indonesia, Yayasan Badan Penerbit Gadjah Mada, Yogyakarta, 1966, page. 6-7,

12 Rakhmat Bowo Suharto, Regulation Urgency Concerning Administrative Sanction Guidelines In Space Administration, Jurnal Pembaharuan Hukum, Volume VI No.3 SeptemberDecember 2019, page.319-331

13 Hans Kelsen, 2007, Teori Umum Hukum dan Negara, alih bahasa oleh Soemardi, Bee Media Indonesia, Jakarta, 2007, page.229-230,

14 Yudi Latif, Loc. Cit., page. 331. 
(UNCLOS). After that, the territory of the Indonesian state was included in the constitution after the 1945 Constitution was amended, and through Article 25A of the Constitution of the Republic of Indonesia it was emphasized that the Unitary State of the Republic of Indonesia was an archipelagic state characterized by an archipelago with an area whose boundaries and rights were determined. by law. Based on this provision, Act No. 43 of 2008 concerning State Territory was born.

d. The affirmation of the singularity of Indonesian citizenship is regulated in Article 26 paragraph (1) of the 1945 Constitution which emphasizes: "Those who become citizens of the State are native Indonesians and people of other nations who are legalized by law as citizens of the State". Furthermore, in paragraph (2) it is emphasized that the requirements regarding State citizenship are stipulated by law. In connection with this mandate, in 1958 Act No. 62 of 1958 concerning Citizenship, which in 1976 was amended by Article 18 through Act No. 3 of 1976 concerning Amendments to Article 18 of Act No. 62 of 1958 concerning Citizenship. This law was later repealed in the reform era and replaced by Act No. 12 of 2006 concerning Citizenship.

e. The form of the State and the government system which is affirmed in Article 1 paragraph (1) of the 1945 Constitution which reads: "The State of Indonesia is a Unitary State in the form of a Republic". With the form of unity, the state power is divided between the central government and local governments. This choice of the form of a Unitary State has consequences on the existence of a Regional Government through Article 18, which is formed to carry out government affairs that are transferred by the Center to its authority. In the context of a unitary state, the state recognizes and respects regional government units that are special or special in nature which are regulated by law.

f. Unity in national culture is formulated in the provisions of Article 32 of the 1945 Constitution, which reads quite simply, namely: "The government advances Indonesia's national culture". Even though it is formulated briefly, the meaning it contains seems to be trying to find a middle ground from the various opinions that have developed among BPUPKI members. This can be seen from the Elucidation of Article 32, which in essence states that national culture is what emerges as a cultural effort of the Indonesian people themselves. The old and original culture that exists as the peaks of culture in regions throughout Indonesia is counted as the national culture.

g. Other means of unifying the Indonesian nationality are the flag, language, national symbols, and the national anthem. In the 1945 Constitution, the unifying facility only regulates the state flag regulated in Article 35 and the state language regulated in Article 36. However, after the amendment of the 1945 Constitution, the regulation regarding the unifying means is complemented by a 
regulation regarding the state symbol which in Article 36A states that the symbol The state is Garuda Pancasila with the motto Unity in Diversity, and the national anthem in Article 36B which reads: "The National Anthem is Indonesia Raya". In relation to the language, flag, state symbol and national anthem, Act No. 24 of 2009 concerning the Flag, Language and National Emblem, as well as the National Anthem. In the section considering letter a of the law, it is stated that the flag, language and symbol of the state, as well as the Indonesian national anthem are a means of unifying, identity, and a manifestation of the nation's existence which is a symbol of state sovereignty and honor.Law as a system in principle can be predicted from accurate knowledge about the condition of the system now. System behavior is determined entirely by the smallest parts of the system. ${ }^{15}$

Various legal provisions both in the realm of the constitution and legislation as described above, show that through the establishment of norms, the law serves as a unifying tool to integrate ethnic, cultural and religious diversity into Indonesia's national identity within the Unitary State of the Republic of Indonesia and maintain and guarantee its maintenance. that union.

The national design constructed by the National legal system shows that unity in the concept of Indonesian nationality is not an attempt to equalize or kill local identity which is reflected in the diversity of aspects of culture, religion and ethnicity, but to build a sense of nationality that can arouse national sentiment that drives an intention. and the realization of the people as one group, one nation. ${ }^{16}$ So, it is this national foundation of Indonesia that will become the knot of unity, capable of expressing unity in diversity, and diversity in unity, which is stated in the country's slogan as "Bhinneka Tunggal Ika". ${ }^{17}$

The thing that underlies the existence of the Indonesian nation is none other than the political ideals to create a country that can bring together values, interests and common ideals. Although culture plays an important role in national unity, the main key that unites this nation is not the similarity of culture, religion and ethnicity, but because of the Unitary Republic of Indonesia which accommodates common political ideals, overcomes all group and individual understandings. ${ }^{18}$

\section{Strengthening the Role of Law in Maintaining the Existence of the Unitary State of the Republic of Indonesia}

In line with the theoretical concept as stated by Ernest Renan and Otto Bauer which has been stated earlier, the existence of the Republic

15 Andri Winjaya Laksana, Manifestation of Pancasila Values In The Omnibus Law For Justice,

The 6th Proceeding International Conference And Call Paper Sultan Agung Islamic University, Vol 1, No 1 (2020), page.164-173

16 Yudi Latif, Loc. Cit., page. 370.

17 Ibid., page. 368.

18 Ibid., page. 359. 
of Indonesia as a nation state will only be upright, especially when the unity among the nation's citizens is maintained. This is also what was conveyed by most of BPUPKI members such as Soekarno, Muh. Yamin, Sosrodinigrat, Woerjaningrat, Soesanto Tirtoprodjo, Ki Bagoes Hadikoesoemo.

By referring to the various opinions that developed in discussions on the formulation of Pancasila and the basis of the State in BPUPKI sessions, unity in the plurality of the Indonesian national house can only be maintained if:

a. There is a binding for the citizens of the nation to become one soul, namely the will to live together.

b. There is mutual cooperation among the nation's citizens;

c. To encourage the spirit of mutual cooperation, the state must be able to protect the entire nation and all Indonesian blood, and provide the common good for its citizens regardless of group, ethnicity or religion;

d. The state shall carry out and continuously develop civic education and multiculturalism that can build a sense of togetherness;

e. The state must ensure a more participatory and non-discriminatory public life;

f. There is citizen loyalty to a set of political and institutional ideals that are considered fair and effective;

g. The state must be able to realize justice and common prosperity;

$\mathrm{h}$. The state must be able to guarantee equal opportunity and social interaction.

If the various prerequisites are narrated in unity, it can be formulated as follows: "Unity in the plurality of the Republic of Indonesia can only be maintained when the state is able to protect all nations and territories, creates a public life that guarantees equality and active participation in state management, is able to realize justice and prosperity, there for all around the glob there are a number of hurdles faced by the common man to have the justice. Justice, many of times it takes years to years but still trails not completed. ${ }^{19}$

If we look at the various provisions in the national legislation, the answer is that the various matters above have been regulated, which can be said to be sufficient from the norm aspect. Associated with the aim of maintaining unity in order to maintain the existence of the Unitary Republic of Indonesia, it seems that the existing legal constructs need to be strengthened by conducting a paradigmatic evaluation as a material for implementing continuous and sustainable legal reform. The evaluation is related to:

a. In countries with a pluralistic culture but united in a national state, the existence of national law that manifests political nationalism,

19 Johny Khoesoema Hioe, Anis Mashdurohatun, Gunarto, Irwan Jasa Tarigan, Reconstruction of Pretrial Institution Function in Supervising Investigator Authorization Based on Justice Value with Moderating Role of Supply Chain Management, International Journal of Supply Chain Management, Vol. 9, No. 3, June 2020, page.613-619 
always faces the problem of pluralism of local laws that always manifests loyalty to local values and needs. Experience has shown that efforts to reconcile the content of national laws with local laws often encounter difficulties. What often happens is the tendency to ignore plural local laws in order to prioritize national laws. If you pay attention to the provisions of the 1945 Constitution of the Republic of Indonesia Article 18B paragraph (2) it clearly reflects the policy of strong legal pluralism that is legalistic. ${ }^{20}$ This is where the importance of Indonesia's legal pluralism policy, to some extent, needs to be reviewed in relation to the legalistic recognition of local laws before national law.

b. In the concept of a nation state, what is called law is definitely more intended to refer to positive law. ${ }^{21}$ Theoretically, legal positivization is often fraught with conflicts of interest which in the end usually reflect more political alignments and are less sensitive to issues of justice. Of course, such a paradigm is often unfavorable when dealing with local legal facts that are not positivity, let alone not by the bearers of state power. Such paradigm needs attention to be immediately corrected, especially in the process of its formation and application which should prioritize affirmation of the values of justice.

c. In a unitary state, there is a stratification between the Central Government which has sovereignty and the Regional Government which is a unitary sub-national government. In addition, according to Article 18B of the 1945 Constitution of the Republic of Indonesia, it is also recognized that regional government units that are special or special in nature and indigenous peoples and their traditional rights. In the name of unity, regional government and customary law community units sometimes become confined by their aspirations so they become less empowered. If we look at every law that regulates regional government, it seems that the regulation of central and regional relations never takes a final form that is consistent with maintaining unity while providing appreciation and empowerment to the regions.

d. Development policies within the framework of achieving state goals often forget to work on software aspects that are components of the nation state, such as culture and social capital. In fact, the wisdom values possessed by local communities in their culture are very important to carry out laws that are full of moral considerations. Evidence that attention to cultural values is still lacking, laws regulating culture only existed and were passed in 2017, even though the provisions regarding the obligation of the Government to promote national culture have existed since the 1945 Constitution was passed. According to Francis Fukuyama, social capital is a series

20 Rikardo Simarmata, Pluralisme Hukum Sebuah Pendekatan Interdisipliner, HuMa, Jakarta, 2005, page. 9 .

21 Soetandyo Wignjosoebroto, Loc. Cit., page. 350. 
of informal values or norms that are shared among members of a group that allow for cooperation between them. ${ }^{22}$

e. As a social reality, social capital is a resource that can be viewed as an investment to obtain new resources. This social capital is contained in social interactions, and is an attribute of a social structure. Because of this nature, the appearance of social capital is more difficult to grasp, even though its functionality is easy to perceive. According to Jousairi Hasbullah, the essence of the study of social capital lies in how the community's ability in an entity or group to work together to build a network to achieve common goals. ${ }^{23}$

f. Plurality in the Unitary State of the Republic of Indonesia is a fact of Indonesian nationality. With pluralism, there must be values, beliefs, or things that are the same, relatively the same, even completely different between cultural, religious, and ethnic communities. The founders of the state have agreed that differences in culture, religion and ethnicity are part of the nation's wealth and remain protected and respected. National unity is not the same culture, religion and ethnicity, but because of the existence of a Unitary state that accommodates common political ideals. Observing recent social and political dynamics, one source of the trigger is the incompleteness of this nation in dividing public and private spaces due to differences between various cultural, religious, or ethnic communities. There is a need for policies that can provide a little certainty about how these differences are placed in discourse or social relations.

The liberalization of political life has more or less brought rational thoughts, full of economic considerations, and pragmatics in achieving the goals of power. The impact is that the values of wisdom, statesmanship, honesty are often not the motivation behind the actions and behavior of citizens in social and political relations. As a result, it is easy for the masses to be brought into conflict by elite interests, or conflicts of interest between citizens or between groups which sometimes erupt into open and anarchist conflicts, mostly due to something trivial.

\section{CONCLUSION}

As a legal system that overcomes the entire existing local legal system, the Indonesian legal system has put in place various integrating tools which are at the same time a national identity that supports pluralism in the building of the Republic of Indonesia. Law has played an important role so that the existence of the Republic of Indonesia is protected from division. The purpose of maintaining unity in order to maintain the existence of the Republic of Indonesia, the law needs to be strengthened by

22 Francis Fukuyama, The Great Disruption, Hakikat Manusia dan Rekonstruksi Tatanan Sosial, Translated by Ruslani, Qalam Press, Yogyakarta, 2002, page. 22.

23 Jousairi Hasbullah, Social Capital (Menuju Keunggulan Budaya Manusia Indonesia), MRUnited Press, Jakarta, 2006, page. 9. 
conducting a paradigmatic evaluation of existing legal constructs related to: (1) legal pluralism policy; (2) legalistic legal paradigm; (3) Central and Regional Relations and local communities; (4) Cultivating aspects of culture and social capital in development policies; (5) division of public and private spaces related to the expression of differences among various cultural, religious or ethnic communities; and (6) Liberalization of political life.

\section{BIBLIOGRAPHY}

\section{Book:}

Bahder Johan Nasution, 2016, Metode Penelitian IImu Hukum, Cetakan Kedua, Mandar Maju, Bandung;

Francis Fukuyama, 2002, The Great Disruption, Hakikat Manusia dan Rekonstruksi Tatanan Sosial, Translated by Ruslani, Qalam Press, Yogyakarta;

Hans Kelsen, 2007, Teori Umum Hukum dan Negara, alih bahasa oleh Soemardi, Bee Media Indonesia, Jakarta;

Joeniarto, 1966, Sejarah Ketatanegaraan Republik Indonesia, Yayasan Badan Penerbit Gadjah Mada, Yogyakarta;

Jousairi Hasbullah, 2006, Social Capital (Menuju Keunggulan Budaya Manusia Indonesia), MR-United Press, Jakarta;

Rikardo Simarmata, 2005, Pluralisme Hukum Sebuah Pendekatan Interdisipliner, HuMa, Jakarta;

Soepomo, 2015, Pergulatan Tafsir Negara Integralistik, Thafa Media, Yogyakarta,;

Soetandyo Wignjosoebroto, 2002, Hukum Paradigma, Metode dan Dinamika Masalahnya, Lembaga Studi dan Advokasi Masyarakat (ELSAM) dan Perkumpulan untuk Pembaharuan Hukum Berbasis Masyarakat dan Ekologi (HuMa), Jakarta;

Yudi Latif, 2015, Negara Paripurna, Historisitas, Rasionalitas dan Aktualitas Pancasila, Gramedia Pustaka Utama, Jakarta;

\section{Journal:}

Andri Winjaya Laksana, Manifestation of Pancasila Values In The Omnibus Law For Justice, The 6th Proceeding International Conference And Call Paper Sultan Agung Islamic University, Vol 1, No 1 (2020);

Emy Hajar Abra, Perubahan Sistem Hukum Menuju Jati Diri Sebuah Negara, Jurnal Pembaharuan Hukum, Volume III No. 2 May - August 2016;

Herlina Ratna Sambawa Ningrum, Analisis Hukum Sistem Penyelesaian Sengketa Atas Tanah Berbasis Keadilan, Jurnal Pembaharuan Hukum, Volume I No. 2 May - August 2014; 
Johny Khoesoema Hioe, Anis Mashdurohatun, Gunarto, Irwan Jasa Tarigan, Reconstruction of Pretrial Institution Function in Supervising Investigator Authorization Based on Justice Value with Moderating Role of Supply Chain Management, International Journal of Supply Chain Management, Vol. 9, No. 3, June 2020;

Oksep Adhayanto, Perkembangan Sistem Hukum Nasional, Jurnal Ilmu Hukum, Volume 4 NO. 2 February-July 2014;

Rakhmat Bowo Suharto, Regulation Urgency Concerning Administrative Sanction Guidelines In Space Administration, Jurnal Pembaharuan Hukum, Volume VI No.3 September-December 2019;

Uyunun Nafisa, Siti Rodhiyah Dwi Istinah, Implementation Of The Vocation School Of Legislation Agency In Village Consultative Department Agreement (Study of The Implementation The Sriwulan Village BPD Sayung, Demak), Jurnal Pembaharuan Hukum, Volume VI No.1 January-April 2019; 